\title{
Perlindungan Hukum Pejabat Notaris Di Pekanbaru Ditinjau Berdasarkan Undang-Undang Jabatan Notaris
}

\author{
Yulfita Rahim ${ }^{1}$, Syafrinaldi ${ }^{2}$, Thamrin $\mathrm{S}^{3}$ \\ ${ }^{1}$ Mahasiswa Program Studi S-3 IImu Hukum, Universitas Islam Riau, Indonesia. \\ E-mail: yulfita.rahim.yr@gmail.com \\ ${ }^{2}$ Fakultas Hukum, Universitas Islam Riau, Indonesia. E-mail: syafrinaldi@law.uir.ac.id \\ ${ }^{3}$ Fakultas Hukum, Universitas Islam Riau, Indonesia. E-mail: tamrins@law.uir.ac.id
}

\begin{abstract}
Notary public in carrying out their profession to provide services and legal services to the community need to get protection and guarantees in order to achieve legal certainty. Guarantee of protection and guarantee of legal certainty on the implementation of notary duties and functions has been stipulated in the Law of the Republic of Indonesia Number 2 of 2014 concerning Amendments to Law No. 30 of 2004 concerning Notarial Positions. This change in the legal basis is intended to further affirm and strengthen the duties, functions, and authority of notary public officials as well as synchronize with other laws. The role of the Notary Department in Indonesia as well as in Pekanbaru City is very important for the community in solving various legal problems faced by the community, one of which is in issuing authentic deed. The professional rights of notary positions, especially regarding civil rights, ideally should get legal protection in carrying out their profession, but in fact Notaries in carrying out their duties often do not get legal protection as they should, as a result notary are faced with civil or criminal legal proceedings.
\end{abstract}

Keywords: Legal Protection, Notary Department, Authentic deed.

\section{Pendahuluan}

Notaris sebagai pejabat umum yang menjalankan profesi dalam memberikan jasa dan pengabdian hukum kepada masyarakat perlu mendapatkan perlindungan dan jaminan demi tercapainya kepastian hukum. Jaminan perlindungan dan jaminan tercapainya kepastian hukum terhadap pelaksanaan tugas dan fungsi Notaris telah diatur dalam Undang-Undang Nomor 30 Tahun 2004 tentang Jabatan Notaris yang telah dirubah berdasarkan Undang-Undang Nomor 2 Tahun 2014 tentang Perubahan Atas UndangUndang Nomor 30 Tahun 2004 tentang Jabatan Notaris (selanjutnya disingkat dengan UUJN). Perubahan dasar hukum ini dimaksudkan untuk lebih menegaskan dan memantapkan tugas, fungsi, dan kewenangan Notaris sebagai pejabat yang menjalankan pelayanan publik, sekaligus sinkronisasi dengan undang-undang lain. ${ }^{1}$

Notaris merupakan bahagian dari lembaga hukum yang diakui di Indonesia dengan memiliki tugas, kewenangan, serta kewajibannya masing-masing. Peran dari Jabatan

\footnotetext{
${ }^{1}$ Widyatmoko, "Analisis Kritis Membedah Ketentuan Undang-Undang Republik Indonesia Nomor 2 Tahun 2014 Tentang Perubahan Atas Undang-Undang Nomor 30 Tahun 2004 Tentang Jabatan Notaris," in Seminar Nasional Program Magister Kenotariatan Fakultas Hukum Serbelas Maret (Surakarta, 2014). HIm. $1-2$
} 
Notaris sangat penting dalam penyelesaian permasalahan hukum, salah satunya adalah dalam menerbitkan akta otentik. Bagi masyarakat yang membutuhkan jasa Notaris dalam menerbitkan akta otentik, tentunya profesi inilah satu-satunya yang dapat menerbitkan.

Soertardjo Soemoatmodjo berpandangan bahwa hak-hak profesi, terutama mengenai hak keperdataannya, idealnya harus mendapatkan perlindungan hukum dalam menjalankan profesinya. Dapat diartikan mengenai hak-hak tersebut adalah mengenai segala kegiatan yang dituntut dalam peraturan perundang-undangan profesi tersebut sebagai tindakan hukum. ${ }^{2}$

Peran serta dan fungsi Jabatan Notaris dilihat dari aspek pelayanan atau pemberian jasa merupakan pejabat yang diberi tugas dan kewenangan oleh negara sebagai pelayan masyarakat di bidang keperdataan, khususnya mengenai pembuatan/penerbitan akta otentik. Seperti disebutkan dalam Pasal 1 Ayat 1 UUJN, "Notaris adalah pejabat umum yang berwenang untuk membuat akta otentik dan memiliki kewenangan lainnya sebagaimana dimaksud dalam Undang-Undang ini atau berdasarkan undang-undang lainnya". ${ }^{3}$

Akta otentik yang diterbitkan Notaris merupakan akta-akta yang memiliki sifat otentik kemudian memiliki dasar kekuatan pembuktian yang sangat sempurna. Bila didefinisikan mengenai arti "akta otentik" seperti yang dijelaskan dalam Pasal 1868 Kitab UndangUndang Hukum Perdata (KUHPerdata) adalah: "Akta otentik ialah suatu akta yang di dalam bentuk yang ditentukan oleh undang-undang, dibuat oleh atau dihadapan pegawai-pegawai umum yang berkuasa untuk itu ditempat dimana akta dibuatnya". ${ }^{4}$

Tidak semua surat disebut sebagai akta otentik, karena suatu akta otentik memiliki 3 (tiga) unsur esenselia yang harus dipenuhi yaitu:

1. Di dalam bentuk yang ditentukan oleh undang-undang;

2. Dibuat oleh dan di hadapan pejabat umum (Notaris);

3. Akta yang dibuat oleh atau di hadapan pejabat umum yang berwenang (Notaris) untuk itu dan di tempat di mana akta itu dibuat. ${ }^{5}$

Isi akta otentik dianggap benar, selama ketidakbenarannya tidak dapat dibuktikan. Akta otentik merupakan alat bukti yang sempurna bagi kedua belah pihak, ahli warisnya, dan atau orang-orang yang mendapatkan hak daripadanya. Pada dasarnya, akta otentik mempunyai 3 (tiga) bentuk kekuatan pembuktian, yaitu: ${ }^{6}$

1. Kekuatan pembuktian formil. Artinya, membuktikan kepastian dan kebenaran sesuatu kejadian serta fakta tersebut dalam akta benar-benar sah telah dilakukan oleh Notaris dan atau telah diterangkan oleh para pihak yang telah menghadap dalam akta telah sesuai kemudian sah berdasarkan prosedur yang telah ditetapkan dalam pembuatan akta oleh Notaris. Akta otentik menjamin kebenaran seperti yang dimaksud adalah mengenai:

\footnotetext{
${ }^{2}$ Soetardjo Soemoatmodjo, Apakah: Notaris, PPAT, Pejabat Lelang (Yogyakarta: Liberty, 1986). HIm. 1

3 Pasal 1 ayat (1) Undang-Undang Republik Indonesia Nomor 2 Tahun 2014 tentang Perubahan Atas Undang-Undang Nomor 30 Tahun 2004 tentang Jabatan Notaris.

${ }^{4}$ Lihat Pasal 1868 Kitab Undang-Undang Hukum Perdata (KUHPerdata).

${ }^{5}$ Irawan Soerodjo, Kepastian Hukum Hak Atas Tanah Di Indonesia (Surabaya: Arkola, 2003). HIm. 148

${ }^{6}$ G.H.S Lumban Tobing, Peraturan Jabatan Notaris (Jakarta: Erlangga, 1983). HIm. 55
} 

a. Tanggal akta itu dibuat;
b. Semua tanda tangan yang tertera dalam akta;
c. Identitas yang hadir sebagai orang yang menghadap Notaris;
d. Semua pihak yang menandatangani akta itu mengakui apa yang diuraikan dalam akta tersebut; dan
e. Tempat dimana akta tersebut dibuat.

2. Kekuatan pembuktian materiil. Artinya, membuktikan antara para pihak, bahwa benar-benar peristiwa yang tersebut dalam akta telah terjadi;

3. Kekuatan pembuktian lahiriah. Artinya, kemampuan dari akta itu sendiri untuk membuktikan dirinya sebagai akta otentik, selanjutnya kemampuan ini menurut Pasal 1875 KUHPerdata tidak dapat diberikan kepada akta yang dibuat di bawah tangan. Selanjutya, melalui akta otentik tidak memerlukan pengakuan dari pihak yang bersangkutan agar mempunyai kekuatan pembuktian yang sempurna, karena akta otentik sudah sesuai dengan ketentuan dalam Pasal 1868 KUHPerdata dan juga telah dibuat oleh pejabat yang berwenang untuk itu, yaitu Notaris.

Mengenai akta otentik seperti yang dijelaskan di atas, dapat dipaparkan bentuknya, yakni berdasarkan Pasal 38 Ayat 1 hingga 4 UUJN dinyatakan: "Setiap Akta terdiri atas: a. awal akta atau kepala akta; b. badan akta; dan c. akhir atau penutup akta". ${ }^{7}$ Ayat 2: "Awal akta atau kepala akta memuat: a. judul akta; b. nomor akta; c. jam, hari, tanggal, bulan, dan tahun; dan d. nama lengkap dan tempat kedudukan Notaris". ${ }^{8}$

Selanjutnya pada Ayat 3 dinyatakan: "Badan akta memuat: a. nama lengkap, tempat dan tanggal lahir, kewarganegaraan, pekerjaan, jabatan, kedudukan, tempat tinggal para penghadap dan/atau orang yang mereka wakili; b. keterangan mengenai kedudukan bertindak penghadap; c. isi akta yang merupakan kehendak dan keinginan dari pihak yang berkepentingan; dan d. nama lengkap, tempat dan tanggal lahir, serta pekerjaan, jabatan, kedudukan, dan tempat tinggal dari tiap-tiap saksi pengenal". ${ }^{9}$

Pada Ayat 4 berbunyi: "Akhir atau penutup akta memuat: a. uraian tentang pembacaan akta sebagaimana dimaksud dalam Pasal 16 ayat (1) huruf $m$ atau Pasal 16 ayat (7); b. uraian tentang penandatanganan dan tempat penandatanganan atau penerjemahan akta jika ada; c. nama lengkap, tempat dan tanggal lahir, pekerjaan, jabatan, kedudukan, dan tempat tinggal dari tiap-tiap saksi akta; dan d. uraian tentang tidak adanya perubahan yang terjadi dalam pembuatan akta atau uraian tentang adanya perubahan yang dapat berupa penambahan, pencoretan, atau penggantian serta jumlah perubahannya". ${ }^{10}$

Landasan filosofis hadirnya UUJN, tidak lain dan tidak bukan adalah, demi terwujudnya jaminan kepastian hukum, ketertiban dan perlindungan hukum yang berlandaskan atas kebenaran serta keadilan berdasarkan akta yang diterbitkannya. Atas dasar ini pula,

\footnotetext{
${ }^{7}$ Republik Indonesia, "Undang-Undang Republik Indonesia Nomor 2 Tahun 2014 Tentang Perubahan Atas Undang-Undang Nomor 30 Tahun 2004 Tentang Jabatan Notaris" (n.d.). Pasal 38 Ayat 1.

8 Republik Indonesia. Pasal 38 Ayat 2.

${ }^{9}$ Republik Indonesia. Pasal 38 Ayat 3.

${ }^{10}$ Republik Indonesia. Pasal 38 Ayat 4.
} 
Notaris wajib hukumnya memberikan kepastian hukum kepada masyarakat selaku klien yang memanfaatkan jasa Jabatan Notaris. ${ }^{11}$

Jabatan Notaris merupakan jabatan kepercayaan (vertrouwenamt), artinya undangundang memberikan kepercayaan yang besar kepada Notaris yang ditunjuk sebagai seorang pejabat umum memberikan kekuatan otentik pada setiap akta yang diterbitkan Notaris. Secara mandiri, jujur, tidak memihak, dengan rasa tanggung jawab, dan profesional. ${ }^{12}$ Mengenai kemampuan profesional Notaris, berarti berbicara mengenai masalah kualitas pelayanan jasa hukum Notaris terhadap klien. Pemenuhan syarat seperti sistematika penerbitan akta otentik dari awal dan akhir akta diterbitkan pejabat Notaris, mencerminkan keadaan yang sebenar-benarnya pada saat pembuatan akta tersebut. ${ }^{13}$

Seorang pejabat Notaris yang hadir berdasarkan peraturan-perundang-undangan yang tegas, dalam tugas dan fungsinya menerbitkan suatu akta menjadi otentik pada saat memenuhi syarat yang telah ditentukan undang-undang, Notaris dimaksud dalam melaksanakan tugas dan fungsinya tersebut berkewajiban menjalankan tugasnya dengan penuh disiplin, profesional, dan memiliki integritas moral yang tinggi serta tidak diragukan lagi. ${ }^{14}$

Namun apabila seseorang Notaris dalam menjalankan jabatannya telah memiliki kemampuan profesional yang tinggi, pengalaman, dan penguasaan ilmu, tetapi pada saat mengamanahkan jabatan Notarisnya tidak dilandasi atas integritas moral, keluhuran martabat, dan etika profesi, maka Notaris tersebut tidak saja merugikan kepentingan klien, melainkan juga akan merusak nama baik Ikatan Notaris Indonesia (I.N.I) sebagai organisasi induk profesi Notaris. ${ }^{15}$

Tentu banyak tanggung jawab dari Notaris, termasuk di antaranya menyimpan dengan baik minuta akta. Seperti diketahui, minuta akta adalah asli akta Notaris, dimana dalam minuta akta ini terdiri dari (dilekatkan) data-data diri para penghadap dan dokumen lain yang diperlukan untuk pembutan akta itu. Karenanya, setiap bulannya, minuta akta mendapat penjilidan menjadi satu buku yang memuat tidak lebih dari 50 (lima puluh) akta. ${ }^{16}$

Fungsi dan tanggung jawabnya Notaris sebagai Pejabat Umum, tidak jarang Notaris berurusan dengan proses hukum, baik pidana ataupun perdata, menyangkut isi akta yang dibuatnya. Pada akhirnya, dari persoalan ini agar nilai-nilai etika dan hukum yang seharusnya dijunjung tinggi oleh Notaris dapat berjalan sesuai dengan peraturan undangundangan yang berlaku, maka sangat diperlukan adanya pengawasan serta perlindungan hukum terhadap Notaris. ${ }^{17}$

\footnotetext{
${ }^{11}$ Habieb Adjie, Meneropong Khasanah Notaris Dan PPAT Indonesia (Bandung: PT. Citra Aditya Bakti, 2009). HIm. 13

${ }^{12}$ C.S.T. Kansil, Pokok-Pokok Etika Profesi Hukum (Jakarta: PT Pradnya Paramita, 1996). HIm. 87-88

${ }^{13}$ Salim HS, Hukum Kontrak-Teori Dan Teknik Penyusunan Kontrak (Jakarta: Sinar Grafika, 2006). HIm. 436

${ }^{14}$ Tan Thong Kie, Studi Notariat (Serba Serbi Praktik Notaris) (Jakarta: Ichtiar Baru Van Hoeve, 2000). HIm. 166

15 Ibid., hal. 89.

${ }^{16}$ Sahat HMT Sinaga, Notaris \& Badan Hukum Indonesia (Jakarta: Jala Permata Aksara, 2019). HIm. 43

${ }^{17}$ Tan Thong Kie, Studi Notariat Serba Serbi Notaris, Intermasa, Jakarta, 2007, hal. 149.
} 
Tulisan ini membahas dan menganalisis dua permasalahan hukum, yaitu tentang peran dan fungsi Jabatan Notaris ditinjau berdasarkan UUJN dan perlindungan hukum terhadap jabatan Notaris di Pekanbaru menurut hukum positif di Indonesia.

\section{Hasil dan Pembahasan}

\section{Peran dan fungsi Jabatan Notaris sebagai Pejabat Publik.}

Berdasarkan amanah UUJN, melalui akta otentik yang dibuatnya akan memberikan jaminan kepastian, ketertiban dan perlindungan hukum bagi masyarakat yang melakukan perbuatan hukum dalam lapangan hukum perdata. Hal ini sejalan dengan Konsiderans UUJN Menimbang huruf b yang berbunyi:

"Bahwa untuk menjamin kepastian, ketertiban dan perlindungan hukum, dibutuhkan alat bukti tertulis yang bersifat otentik mengenai perbuatan, perjanjian, penetapan dan peristiwa hukum yang dibuat di hadapan atau oleh pejabat yang berwenang." 18

Secara umum, Notaris adalah merupakan profesi khusus yang lahir berdasarkan keahlian. Menurut klasifikasi pekerjaan, profesi merupakan pekerjaan dalam arti khusus, yaitu pekerjaan yang memiliki kriteria sebagai berikut: ${ }^{19}$

1. Bidang pekerjaannya tertentu (spesialisasi);

2. Berdasarkan keahlian dan keterampilan khusus;

3. Bersifat tetap dan terus menerus;

4. Lebih mendahulukan pelayanan daripada imbalan (pendapatan);

5. Adanya pertanggungjawaban kepada diri sendiri dan kepada masyarakat;

6. Adanya pengakuan dari masyarakat;

7. Adanya organisasi atau asosiasi profesi;

8. Adanya kode etik profesi. ${ }^{20}$

Berdasarkan uraian tersebut di atas, Notaris mempunyai kedudukan dan peran sebagai berikut:

1. Kedudukan Notaris adalah sebagai wakil negara (pejabat umum) dalam urusan perdata yang berkaitan dengan pembuatan akta otentik, sehingga dengan demikian kedudukan Notaris adalah sebagai abatan. Kedudukan Notaris ini ditegaskan dalam UUJN pada bagian Menimbang huruf c yang berbunyi: "bahwa notaris sebagai pejabat umum yang menjalankan profesi dalam memberikan jasa hukum kepada masyarakat...";

2. Fungsi Notaris adalah bertindak (dalam jabatannya) dalam pembuatan akta otentik berkaitan dengan perbuatan hukum dalam lapangan hukum perdata. Fungsi Notaris ini ditegaskan dalam UUJN Pasal 1 angka 1 yang berbunyi: "Notaris adalah pejabat umum yang berwenang untuk membuat akta otentik dan memiliki kewenangan lainnya sebagaimana dimaksud dalam undang-undang ini atau

\footnotetext{
${ }^{18}$ Konsiderans Menimbang huruf b Undang-Undang Nomor 2 Tahun 2014 tentang Perubahan Atas Undang-Undang Nomor 30 Tahun 2004 tentang Jabatan Notaris.

19 Bachruddin, Hukum Kenotariatan Membangun Sistem Kenotariatan Indonesia Berkeadilan (Bandung: PT Refika Aditama, 2019). Hlm. 16-17

${ }^{20}$ Abdul Ghofur Anshori, Lembaga Kenotariatan Indonesia Perspektif Hukum Dan Etika, Cetakan I (Yogyakarta: UH Press, 2009). Hlm. 26-29
} 
berdasarkan undang-undang lainnya.";

3. Peran Notaris adalah memberikan jaminan kepastian, ketertiban dan perlindungan hukum bagi masyarakat yang melakukan perbuatan hukum dalam lapangan hukum perdata melalui akta otentik yang dibuat oleh atau di hadapan Notaris. Peran Notaris ini ditegaskan dalam UUJN pada bagian Menimbang huruf b yang berbunyi: "bahwa untuk menjamin kepastian, ketertiban dan perlindungan hukum, dibutuhkan alat bukti tertulis yang bersifat otentik mengenai perbuatan, perjanjian, penetapan dan peristiwa hukum yang dibuat di hadapan atau oleh pejabat yang berwenang."

Notaris merupakan suatu pekerjaan, profesi, usaha atau jabatan, sesungguhnya dapat ditelusuri dari bunyi Pasal 1868 KUH Perdata dan Pasal 1 angka 1 UUJN yaitu: Pasal 1868 KUH Perdata: ${ }^{21}$

"Suatu akta otentik ialah suatu akta yang dibuat dalam bentuk yang ditentukan undang-undang oleh atau di hadapan pejabat umum yang berwenang untuk itu di tempat akta itu dibuat." Pasal 1 angka 1 UUJN: ${ }^{22}$

"Notaris adalah pejabat umum yang berwenang untuk membuat akta otentik dan memiliki kewenangan lainnya sebagaimana dimaksud dalam undang- undang ini atau berdasarkan undang-undang lainnya."

Berdasarkan bunyi kedua pasal tersebut di atas, dengan jelas disebutkan bahwa Notaris adalah pejabat umum. Dalam kapasitasnya sebagai pejabat umum, notaris diberikan kewenangan oleh undang-undang untuk membuat akta otentik dan kewenangan lainnya, baik berdasarkan UUJN maupun undang-undang lainnya.

Undang-Undang Nomor 2 Tahun 2014 tentang Perubahan Atas Undang-Undang Nomor 30 Tahun 2004 tentang Jabatan Notaris pada hakikatnya mengatur tentang pembentukkan Jabatan Notaris oleh negara sekaligus pemberian kewenangan atas jabatan tersebut. Berkaitan dengan Notaris, maka kewenangan adalah sesuatu yang dilekatkan pada jabatan yang dibentuk oleh negara melalui Undang-Undang Nomor 2 Tahun 2014 tentang Perubahan Atas Undang-Undang Nomor 30 Tahun 2004 tentang Jabatan Notaris, bukan dilekatkan pada pejabatnya atau orangnya. Orangnya adalah subjek hukum yang dipilih atau diangkat untuk menjalankan jabatan notaris dan disebut sebagai pejabat, ${ }^{23}$ dalam hal ini pejabat umum (openbare ambtenaren). Jabatan notaris dijalankan melalui pejabatnya atau pemegang jabatan, dan dalam kapasitasnya tersebut, pejabat notaris menjalankan hak dan kewajiban Jabatan Notaris. ${ }^{24}$

Sesuai asas legalitas, UUJN merupakan dasar legalitas bagi lahirnya Jabatan Notaris beserta kewenangan jabatan. Unsur "kewenangan" yang diberikan oleh undang-undang

\footnotetext{
${ }^{21}$ Pemerintah Hindia Belanda, "Kitab Undang Undang Hukum Perdata Di Indonesia," Pub. L. No. 23 (1847). Pasal 1868

${ }^{22}$ Republik Indonesia, Undang-Undang Republik Indonesia Nomor 2 Tahun 2014 tentang Perubahan Atas Undang-Undang Nomor 30 Tahun 2004 tentang Jabatan Notaris. Pasal 1 angka 1

${ }^{23}$ Abdul Ghofur Anshori, Lembaga Kenotariatan Indonesia Perspektif Hukum Dan Etika. Hlm. 26-29

${ }^{24}$ Abdul Ghofur Anshori. Hlm. 26-29
} 
kepada Jabatan Notaris oleh negara sebagai wakil negara dalam urusan perdata, yaitu berwenang dalam hal pembuatan akta otentik. ${ }^{25}$

Wewenang merupakan alat atau "onderdel" atau bagian tertentu dari kewenangan atau perkataan lain di dalam kewenangan terdapat wewenang-wewenang (rechsbe voegdheden). ${ }^{26} \mathrm{Hal}$ ini bersesuaian dengan definisi wewenang dari Gabrielle Ferrazi yaitu sebagai hak untuk menjalankan satu atau lebih fungsi manajemen, yang meliputi pengaturan (regulasi dan standarisasi), pengurusan (administrasi) dan pengawasan (supervisi) atas suatu urusan tertentu. ${ }^{27}$

\section{Perlindungan Hukum terhadap Jabatan Notaris di Pekanbaru Menurut Hukum Positif}

Pendapat para ahli lainnya juga memaparkan tentang 'perlindungan hukum' di antaranya adalah yang disampaikan Satjipto Raharjo. Menurutnya, 'perlindungan hukum' merupakan pemberian pengayoman kepada hak asasi manusia (HAM) yang merasa dirugikan oleh orang lain, akibatnya perlindungan hukum tersebut diberikan kepada masyarakat supaya mereka dapat menikmati hak-hak hukum yang diberikan. Kata lain, perlindungan hukum adalah upaya-upaya hukum yang wajib diberikan oleh para penegak hukum agar menimbulkan rasa aman pikiran maupun fisik dari berbagai gangguan dan ancaman dari pihak mana pun. ${ }^{28}$

Sedangkan penafsiran Philipus M. Hadjon tentang 'perlindungan hukum' adalah, perlindungan terhadap harkat, martabat, dan pengakuan terhadap HAM yang dimiliki setiap subjek hukum berdasarkan ketentuan yang berlaku sebagai kumpulan peraturan yang dapat melindungi suatu hal dari sebab lainnya. ${ }^{29}$

Bagi Setiono, perlindungan hukum diartikan sebagai tindakan untuk melindungi masyarakat dari perbuatan sewenang-wenang penguasa yang bertentangan dengan ketentuan hukum yang berlaku agar lahir hidup tertib dan tentram dan mewujudkan masyarakat dapat merasakan martabatnya sebagai manusia. ${ }^{30}$ Lain hal yang dinyatakan Muchsin, perlindungan hukum adalah rangkaian kebijakan melindungi setiap individu masyarakat dihubungkan dengan nilai dan kaidah dalam sikap serta tindakan agar terciptanya ketertiban hidup antar manusia. ${ }^{31}$

Dikaitkan dengan pengakuan dan perlindungan terhadap hak asasi manusia, pengakuan dan perlindungan terhadap hak asasi manusia mendapat tempat utama dan dapat dikaitkan dengan tujuan dari suatu negara hukum. Mengenai prinsip perlindungan hukum terhadap tindakan pemerintah bersumber dari konsep tentang perlindungan dan

25 Ateng Syarifuddin, Hukum Kenotariatan Membangun Sistem Kenotariatan Indonesia Berkeadilan, Jurnal Pro Justisia, vol. 4, 2000. Hlm. 22

26 Nuryanto A. Daim, Hukum Administrasi, Perbandingan Penyelesaian Maladministrasi oleh Ombudsman dan Pengadilan Tata Usaha Negara, Cetakan I, Penerbit Laksbang Justisia, Surabaya, 2014, hal. 39.

27 Ganjong, Pemerintah Daerah, Kajian Politik dan Hukum, Penerbit Ghalia Indonesia, Bogor, 2007, hal. 93.

${ }^{28}$ Satjipto Raharjo, Ilmu Hukum, Cetakan ke-V 2000, Citra Aditya Bakti, Bandung, 2000, hal. 74.

${ }^{29}$ Philipus M. Hadjon, Perlindungan Bagi Rakyat di Indonesia, Bina Ilmu, Surabaya, 1987, hal. 25.

30 Setiono, Rule of Law (Supremasi Hukum), Penerbit Universitas Sebelas Maret, Surakarta, 2004, hal. 4.

31 Muchsin, Perlindungan dan Kepastian Hukum bagi Investor di Indonesia, Penerbit Universitas Sebelas Maret, Surakarta, 2003, hal. 14. 
pengakuan terhadap hak asasi manusia. Mendasari perlindungan hukum terhadap kebijakan pemerintahan adalah prinsip dari negara hukum itu sendiri. ${ }^{32}$

Bila dikaitkan dengan profesi seorang Notaris, hakikatnya mengemban dua sisi hak dan kewajiban dalam dirinya. Selain mengemban hak dan kewajiban sebagai pejabat umum yaitu wakil negara dalam urusan perdata, secara lahiriah seorang individu Notaris juga manusia yang kodratnya adalah ciptaan Allah SWT yang mempunyai kodrati manusia yang disebut hak asasi manusia, di antaranya hak untuk hidup layak, hak untuk memperoleh keadilan dan memperoleh perlindungan hukum.

Hakikat dari Jabatan Notaris adalah jabatan yang berkesinambungan, artinya seorang individu warga negara yang diangkat sebagai Notaris diharapkan untuk menjalankan jabatannya secara terus menerus sampai dengan pensiun. Berdasarkan hakikatnya, keberadaan atau eksistensi seorang Notaris dalam dirinya mengemban dua fungsi dan kedudukan pada saat yang bersamaan dan tidak dapat terpisahkan, yaitu fungsi dan kedudukan sebagai jabatan dan sebagai individu warga negara. ${ }^{33}$

UUJN menjadikan Notaris sebagai pejabat publik, sehingga akibat hukumnya dalam akta Notaris mendapat kedudukan yang otentik dan mempunyai sifat eksekutorial. Kekuatan keotentikan suatu akta notaris bukan dikarenakan proses pembuatan akta tersebut didasarkan kepada bentuk yang sudah ditetapkan oleh undang-undang, dan dibuat oleh atau di hadapan pejabat yang berwenang.

Berdasarkan UU Jabatan Notaris sebenarnya dari dasar hukum ini, Jabatan Notaris telah merasa dilindungi apabila dalam menjalankan profesinya berdasarkan ketentuan, hukum yang berlaku, serta melekat asas-asas yang dianut dalam Jabatan Notaris. Asas yang berkenaan dengan tugas dan Jabatan Notaris terutama dalam pembuatan akta otentik terbagi ke dalam dua asas, yang bersifat formil atau prosedur dan asas yang bersifat materil.

Asas yang bersifat formal dalam menjalankan Jabatan Notaris menyangkut asas yang berkenaan dengan prosedur yang harus dipenuhi dalam setiap membuat keputusan atau ketetapan (membuat akta otentik) atau asas-asas yang berkaitan tata cara menjalankan tugas Jabatan Notaris, terkhususnya di Kota Pekanbaru yang meliputi asas-asas yang berkaitan dengan proses persiapan dan proses pembentukan keputusan, dan asas-asas yang berkaitan dengan pertimbangan serta susunan keputusan. Asas formil ini meliputi: ${ }^{34}$

\section{Asas kepercayaan}

Jabatan Notaris merupakan jabatan kepercayaan yang harus selaras dengan mereka yang menjalankan tugas Jabatan Notaris sebagai orang yang dipercaya. Notaris sebagai jabatan yang kepercayaan tidak berarti apa-apa jika ternyata mereka menjalankan tugas jabatan sebagai Notaris adalah orang yang tidak dapat

\footnotetext{
32 Philipus M. Hadjon, Perlindungan bagi Rakyat di Indonesia, Penerbit Bina Ilmu, Surabaya, 1987, hal. 30.

${ }^{33}$ Bachruddin Dkk, Op. Chit., hal. 21.

${ }^{34}$ M. Luthfi Hadi Darus, Hukum Notariat dan Tanggungjawab Jabatan Notaris, UII Press Yogyakarta, Yogyakarta, 2017, hal. 34.
} 
dipercaya. ${ }^{35}$ Asas kepercayaan merupakan suatu asas yang menyatakan bahwa Jabatan Notaris dilandasi oleh hubungan kepercayaan antara Notaris dengan kliennya.

Keinginan masyarakat untuk membuat akta otentik kepada Notaris, semata-mata dilandasi oleh kepercayaan. Asas kepercayaan juga disebut legal expectation, harapan-harapan yang ditimbulkan (janji-janji, keterangan-keterangan, aturanaturan kebijaksanaan dan rencana-rencana) sebisa mungkin harus dipenuhi. Bentuk dari Jabatan Notaris sebagai jabatan kepercayaan sebagaimana yag terdapat dalam Pasal 16 (1) huruf (a) UUJN yang menyatakan, "dalam menjalankan jabatannya, notaris wajib bertindak amanah, jujur". ${ }^{36}$

\section{Asas kehati-hatian}

Notaris dalam melakukan suatu tindakan hukum harus senantiasa bertindak secara hati-hati agar Notaris sebelum mengambil keputusan, meneliti semua fakta yang relevan dalam pertimbangannya berdasarkan kepada peraturan perundang-undangan yang berlaku. Meneliti semua kelengkapan dan keabsahan alat bukti atau dokumen yang diperlihatkan kepada Notaris, serta mendengar keterangan atau pernyataan para penghadap wajib dilakukan sebagai dasar pertimbangan untuk dituangkan di dalam akta. Apabila Notaris kurang teliti dalam memeriksa fakta-fakta penting, itu berarti Notaris bertindak tidak hati-hati. Asas kehati-hatian ini merupakan aplikasi dari Pasal 16 ayat 1 huruf a yang menyatakan, "dalam menjalankan jabatannya notaris wajib bertindak seksama."

Asas kehati-hatian adalah suatu asas yang menyatakan, bahwa Notaris dalam menjalankan fungsi dan jabatannya wajib menerapkan prinsip kehati-hatian dalam rangka melindungi kepentingan masyarakat yang dipercayakan padanya. Tujuan diberlakukannya prinsip kehati-hatian tidak lain adalah agar notaris selalu dalam rambu-rambu yang benar. Dengan diberlakukannya prinsip kehati-hatian diharapkan agar kepercayaan masyarakat terhadap Notaris tetap tinggi, sehingga masyarakat bersedia dan tidak ragu-ragu menggunakan jasa Notaris.

\section{Asas pemberian alasan}

Setiap akta yang dibuat di hadapan atau oleh notaris harus mempunyai alasan dan fakta yang mendukung untuk akta yang bersangkutan atau ada pertimbangan hukum yang harus dijelaskan kepada para pihak/penghadap. Setiap akta ataupun perbuatan Notaris dalam memformulasikan akta otentik harus memberikan alasan, harus ada dasar fakta yang teguh dan alasannya harus mendukung.

Fakta yang menjadi titik tolak sebagai dasar pertimbangan dalam pembuatan_akta otentik harus benar. Bila ternyata bahwa fakta-fakta pokok berbeda dari apa yang dikemukakan atau diterima oleh notaris, maka dasar fakta yang teguh dari alasan-

\footnotetext{
${ }^{35}$ Habieb Adjie, Sanksi Perdata Dan Administratif Terhadap Notaris Sebagai Pejabat Publik (Bandung: Refika Aditama, 2009). Hlm. 83

${ }^{36}$ Lihat Pasal 16 (1) huruf (a) Undang-Undang Nomor 2 Tahun 2014 tentang Perubahan Atas Undang-Undang Nomor 30 Tahun 2004 tentang Jabatan Notaris.
} 
alasan tidak ada. Dalam hal ini terdapat cacat dalam kehati-hatian. Asas ini sangat erat kaitannya dengan asas kehati- hatian.

\section{Asas proporsionalitas}

Keadilan menuntut tindakan secara proporsional, artinya sesuai, seimbang dan selaras dengan hak dan kewajiban setiap orang. Karena itu, setiap notaris dalam melakukan tindakannya harus selalu memperhatikan aspek keadilan ini. Sedangkan kewajaran meberi penekanan agar Jabatan Notaris memperhatikan nilai-nilai yang berlaku di masyarakat, agama, ketertiban umum, maupun nilainilai lainnya. Asas ini lebih mengutamakan keseimbangan antara hak dan kewajiban.

Asas proporsionalitas ini merupakan penerapan dari Pasal 16 ayat 1 huruf (a), yang menyatakan, "bahwa, dalam menjalankan tugasnya notaris wajib tidak berpihak, dan menjaga kepentingan pihak yang terkait dalam perbuatan hukum. " ${ }^{37}$ Di sisi lain, Notaris juga wajib mengutamakan keseimbangan antara hak dan kewajiban para penghadap sebelum menuangkan ke dalam akta otentik.

\section{Asas profesionalitas}

Asas profesionalitas adalah asas yang mengutamakan keahlian yang berlandaskan kode etik dan ketentuan Undang-Undang Jabatan Notaris yang berlaku dalam menjalankan tugas dan Jabatan Notaris. Penerapan asas profesiolitas ini terdapat dalam Pasal 16 ayat 1 huruf (d) yang menyatakan, bahwa "notaris dapat memberikan pelayanan sesuai dengan ketentuan dalam UUJN, kecuali ada alasan untuk menolaknya." ${ }^{38}$ Asas ini mengutamakan kepada keahlian (keilmuan) dan ketrampilan Notaris dalam menjalankan jabatannya dengan menegakan kode etik dan berdasarkan UU Jabatan Notaris.

\section{Asas kerahasiaan terbatas}

Asas kerahasiaan terbatas juga merupakan hak ingkar bagi Notaris dalam menjalankan jabatannya (verchoningsplicht). Asas rahasia terbatas sebagaimana yang terdapat dalam Pasal 16 (1) huruf (f) UU Jabatan Notaris, yang mewajibkan notaris untuk merahasiakan segala sesuatu mengenai akta yang dibuatnya dan segala keterangan yang diperoleh guna pembuatan akta sesuai dengan sumpah/janji jabatan, kecuali undang-undang menentukan lain. ${ }^{39}$

Lebih lanjut, apabila Notaris membuka rahasia yang seharusnya dijaga, maka Notaris juga telah melanggar hukum pidana karena membuka rahasia yang seharusnya tidak disampaikan kepada pihak lain. Bahwa apabila dilihat dari sisi jabatannya, Notaris tersebut juga dapat dikategorikan lelah melakukan tindak pidana tentang menyalahgunakan kewenangan atau jabatannya. Berkaitan dengan masalah rahasia Jabatan Notaris, dalam pembahasan mengenai Pasal 17

\footnotetext{
37 Ibid.

38 Lihat Pasal 16 (1) huruf (d) Undang-Undang Nomor 2 Tahun 2014 tentang Perubahan Atas Undang-Undang Nomor 30 Tahun 2004 tentang Jabatan Notaris.

${ }^{39}$ Lihat Lihat Pasal 16 (1) huruf (d) Undang-Undang Nomor 2 Tahun 2014 tentang Perubahan Atas Undang-Undang Nomor 30 Tahun 2004 tentang Jabatan Notaris.
} 
dan 40 UU Jabatan Notaris yang pada intinya berisikan kewajiban Notaris merahasiakan isi akta.

\section{Asas persamaan}

Dalam memberikan pelayanan kepada masyarakat dengan tidak membedabedakan satu dengan lainnya berdasarkan keadaan sosial ekonomi atau alasan lainnya. Alasan-alasan seperti ini tidak dibenarkan dilakukan oleh Notaris dalam melayani masyarakat, hanya alasan hukum yang boleh dijadikan dasar, bahwa Notaris tidak dapat memberikan jasa kepada yang menghadap. Bahkan dalam keadaan tertentu, Notaris wajib memberikan jasa hukum di bidang kenotariatan secara cuma-cuma kepada yang tidak mampu sebagaimana yang terdapat di dalam Pasal 37 UUJN.

Dalam rangka prinsip persamaan ini, segala sikap dan tindakan diskriminatif dalam segala bentuk dan manifestasinya diakui sebagai sikap dan tindakan yang terlarang, kecuali tindakan-tindakan yang bersifat khusus dan sementara yang dinamakan 'affirmative actions' guna mendorong dan mempercepat kelompok masyarakat tertentu atau kelompok warga masyarakat tertentu untuk mengejar kemajuan sehingga mencapai tingkat perkembangan yang sama dan setara dengan kelompok masyarakat kebanyakan yang sudah jauh lebih maju. ${ }^{40}$

Kelompok masyarakat tertentu yang dapat diberikan perlakuan khusus melalui 'affirmative actions' yang tidak termasuk pengertian diskriminasi itu misalnya adalah, kelompok masyarakat suku terasing atau kelompok masyarakat hukum adat tertentu yang kondisinya terbelakang. Sedangkan kelompok warga masyarakat tertentu yang dapat diberi perlakuan khusus yang bukan bersifat diskriminatif. ${ }^{41}$

\section{Asas kepastian hukum}

Asas kepastian hukum adalah asas dalam negara hukum yang mengutamakan landasan peraturan perundang-undangan, kepatutan dan keadilan yang wajib dipatuhi Notaris dalam menjalankan tugas dan jabatannya yang berhubungan dengan segala tindakannya dalam pembuatan akta otentik. Dari asas kepastian hukum membawa serta bahwa akta otentik yang telah dibuat harus memberikan penafsiran/kepastian hukum sesuai dengan hak dan kewajiban para pihak.

Berdasarkan Pasal 16 ayat 1 UUJN dinyatakan, bahwa dalam menjalankan jabatannya, "notaris berkewajiban bertindak jujur, saksama, mandiri, tidak berpihak, dan menjaga kepentingan pihak yang terkait" dalam perbuatan hukum sehingga akta yang dibuatnya harus memberikan kepastian hukum. ${ }^{42}$ Sedangkan di dalam UUJN maupun Kode Etik Notaris, Notaris dituntut untuk bertindak secara jujur, saksama, mandiri, tidak berpihak. Apabila hal ini dilanggar, maka bagaimana

\footnotetext{
${ }^{40}$ Jimly Asshiddiqie, "Gagasan Negara Hukum". Melalui http://wsvw.Jimly.com/Makalah/ /Konsep, Selasa, 04 April 2021, pukul 16.00 WIB.

${ }^{41}$ Habib Adjie (II), Op. Cit., hal. 83.

${ }^{42}$ Habib Adjie (II). Op. Cit., hal. 83.
} 
mungkin Notaris dapat menjaga kepentingan pihak-pihak yang terkait. Untuk itu, Notaris dituntut untuk bertindak secara netralitas dan profesional.

\section{Asas larangan bertindak sewenang-wenang dan penyalahgunaan wewenang}

Kewenangan Notaris secara umum mencakup tiga hal, kewenangan dari segi material (sebagaimana yang terdapat dalam Pasal 15 UUJN), kewenangan dari segi wilayah/yurisdiksi (Pasal 18 UU Jabatan Notaris) dan kewenangan dari segi waktu. Seorang pejabat pemerintah memiliki wewenang yang sudah ditentukan dalam aturan perundang-undangan baik dari segi material, wilayah maupun waktu.

Notaris yang melakukan perbuatan melebihi apa yang menjadi kewenangannya, maka tindakan Notaris tersebut dapat digolongkan sebagai tindakan penyalahgunaan kewenangan. Sehingga pihak yang mendapatkan kerugian akibat penyalahgunaan wewenang dapat meminta pertanggungjawaban kepada Notaris tersebut.

\section{Asas praduga sah}

Asas ini merupakan agar setiap tindakan pemerintah (pejabat publik) selalu dianggap ada asas praduga (rechmatig) sampai ada pembatalannya atau lebih dikenal dengan presumtio lustae causa, yang maksudnya keputusan tata negara harus dianggap sah selama belum dibuktikan sebaliknya, sehingga pada prinsipnya harus selalu dapat segera dilaksanakan. ${ }^{43}$

Secara umum, di Provinsi Riau, berdasarkan data dari Majelis Pengawas Wilayah Notaris (MPWN) Provinsi Riau, dari tahun 2015 hingga 2020 terdapat 517 Pejabat Notaris. Selanjutnya, berdasarkan rekapitulasi penanganan perkara pengaduan/pelaporan masyarakat terhadap dugaan pelanggaran perilaku dan pelaksanaan Jabatan Notaris yang disampaikan ke MPWN Provinsi Riau dimana dari tahun 2015 hingga 2020 terdapat enam pengaduan masyarakat. Dari enam pengaduan/pelaporan tersebut ke MPWN Provinsi Riau, empat pengaduan/pelaporan merupakan tembusan ke MPWN Provinsi Riau dan atas dua pengaduan/pelaporan tersebut diusulkan untuk diberhentikan secara tidak hormat dari Jabatan Notarisnya.

Dapat dijabarkan, berdasarkan enam pengaduan/pelaporan ke MPWN Provinsi Riau tersebut yang juga merupakan pelaporan berupa tembusan, terkhusus Jabatan Notaris di Kota Pekanbaru, terdapat tiga pengaduan/pelaporan di tahun 2017 yang disampaikan oleh 3 (tiga) orang warga masyarakat Kota Pekanbaru atas dugaan kesalahan oknum Notaris di Pekanbaru, satu di antaranya dalam perkara dugaan menerbitkan kuasa menjual. Kemudian, dua laporan/pengaduan lagi ke MPWN Provinsi Riau diusulkan untuk diberhentikan secara tidak hormat dari Jabatan Notarisnya, yakni atas pengaduan/laporan dari dua masyarakat Kota Pekanbaru yang berbeda terhadap dua oknum Notaris yang berbeda pula di wilayah kerja Kota Pekanbaru di tahun 2017. Dalam

43 Paulus Efendi Lotulung, Beberapa Sistem Tentang Kontrol Segi Hukum Terhadap Pemerintah Seri Ke-1: Perbandingan Hukum Administrasi dan Sistem Peradilan Administrasi (Edisi II dengan revisi), Citra Aditya Bakti, Bandung, 1993, hal. 118. 
hal ini, MPWN Provinsi Riau masih memproses atas laporan/pengaduan dari beberapa perkara ini.

\section{Kesimpulan}

Berdasarkan jabatannya, profesi Notaris di Kota Pekanbaru berkewajiban bertindak jujur, saksama, mandiri, tidak berpihak, dan menjaga kepentingan pihak yang terkait dalam melakukan aktivitas hukum sehingga akta yang diterbitkan harus memberikan kepastian hukum. Apabila Jabatan Notaris tidak berlaku jujur dalam menjalankan tugas dan fungsinya sebagai pejabat pembuat akta, maka akta yang diterbitkan tidak dapat memberikan kepastian hukum kepada para pihak yang melakukan aktivitas hukum tersebut. Selanjutnya, ketika pejabat Notaris sikapnya tidak seksama, maka akta yang diterbitkan dapat menimbulkan potensi konflik dikarenakan aktanya tidak dapat memberikan kepastian hukum kepada para pihak yang menghadap. Begitu juga apabila Notaris dalam menjalankan jabatannya tidak mandiri, secara sederhana Notaris akan berpihak kepada salah satu pihak yang menghadap.

Apabila Jabatan Notaris di Kota Pekanbaru dalam menjalankan profesinya tidak berdasarkan ketentuan yang Kode Etik Notaris, bertentangan dengan hukum yang berlaku, serta tidak melekat asas-asas yang dianut dalam Jabatan Notaris, secara otomatis tidak akan bisa menjaga kepentingan hukum para pihak yang terkait. Bukannya kepastian hukum yang akan didapat oleh para pihak, justru sebaliknya akan menyebabkan para pihak atau salah satu pihak kehilangan hak karena tidak adanya kepastian hukum yang didapat. 


\section{Daftar Pustaka}

Abdul Ghofur Anshori, Lembaga Kenotariatan Indonesia Perspektif Hukum dan Etika, Cetakan I, UH Press, Yogyakarta, 2009.

Abu Ahmadi, Sosiologi Pendidikan: Membahas Gejala Pendidikan dalam Konteks Struktur Sosial Masyarakat, Bina Ilmu, Jakarta, 1982.

Ahmad Fedyani Saifulddin, Antropologi Sosial Budaya, Institute Antropologi Indonesia, Depok, 2011.

Amiruddin dan Zainal Asikin, Pengantar Metode Penelitian Hukum, PT. Raja Grafindo Persada, Jakarta, 2006.

Ateng Syafrudin, Menuju Penyelenggaraan Pemerintahan Negara yang Bersih dan Bertanggungjawab, Jurnal Pro Justisia Edisi IV, Penerbit Universitas Parahyangan Bandung, 2000.

Bachruddin Dkk, Hukum Kenotariatan Membangun Sistem Kenotariatan Indonesia Berkeadilan, PT Refika Aditama, Bandung, 2019.

Bambang Waluyo, Penelitian Hukum Dalam Praktek, Sinar Grafika, Jakarta, 1996.

Cholid Narbuko dan Abu Achmadi, Metodologi Penelitian, PT. Bumi Aksara, Jakarta, 2002.

C.S.T. Kansil, Pengantar IImu Hukum dan Tata Hukum Indonesia, Balai Pustaka, Jakarta 1989.

Pokok-pokok Etika Profesi Hukum, PT Pradnya Paramita, Jakarta, 1996.

F. Sugeng Susanto, Penelitian Hukum, CV. Ganda, Yogyakarta, 2007.

Ganjong, Pemerintah Daerah, Kajian Politik dan Hukum, Penerbit Ghalia Indonesia, Bogor, 2007.

G.H.S Lumban Tobing, Peraturan Jabatan Notaris, Erlangga, Jakarta, 1983.

Habieb Adjie, Meneropong Khasanah Notaris dan PPAT Indonesia, PT. Citra Aditya Bakti, Bandung, 2009.

Sanksi Perdata dan Administratif Terhadap Notaris Sebagai Pejabat Publik, Refika Aditama, Bandung, 2009.

Herlien Budiono, Kumpulan Tulisan Hukum Perdata di Bidang Kenotariatan, PT. Citra Aditya Bakti, 2008, Bandung.

Husaini Usman dan Purnomo Setiady Akbar, Metodologi Penelitian Sosial, PT. Bumi Aksara, Jakarta, 2003.

H.A. Fuad Ihsan, Filsafat IImu, Cetakan Pertama, Rineka Cipta, Jakarta, 2010.

Irawan Soerodjo, Kepastian Hukum Hak Atas Tanah di Indonesia, Arkola, Surabaya, 2003. Ishaq, Penulisan Skripsi, Tesis, serta Disertasi, Alfabeta, Bandung, 2017.

Johny Ibrahim, Teori dan Metodologi Penelitian Hukum Normatif, Bayu Media Publishing, Malang, 2009. 
Khudzaifah Dimyati dan Kelik Wardiono, Metode Penelitian Hukum, Fakultas Hukum, Surakarta, 2004.

Mardalis, Metode Penelitian Suatu Pendekatan Proposal, Bumi Aksara, Jakarta, 2010.

Moekijat, Manajemen Sumber Daya Manusia, CV. Mandar Maju, Bandung, 2010.

Mukti Fajar ND dan Yulianto Achmad, Penelitian Hukum Normatif dan Hukum Empiris, Pustaka Pelajar, Yogyakarta, 2010.

Moh. Kusnardi dan Harmaily Ibrahim, Hukum Tata Negara Indonesia, Sinar Bakti, Jakarta, 1988.

Muchsin, Perlindungan dan Kepastian Hukum bagi Investor di Indonesia, Penerbit Universitas Sebelas Maret, Surakarta, 2003.

Munir Fuady, Teori Negara Hukum Modern (Rehctstaat), Refika Aditama, Bandung, 2009.

M. Luthfi Hadi Darus, Hukum Notariat dan Tanggungjawab Jabatan Notaris, UII Press Yogyakarta, Yogyakarta, 2017.

Nuryanto A. Daim, Hukum Administrasi, Perbandingan Penyelesaian Maladministrasi oleh Ombudsman dan Pengadilan Tata Usaha Negara, Cetakan I, Penerbit Laksbang Justisia, Surabaya, 2014.

Nining Haslinda Zainal, Analisis Kesesuaian Tugas Pokok dan Fungsi dengan Kompetensi, Penerbit Universitas Hasanuddin, Makassar, 2008.

Paulus Efendi Lotulung, Beberapa Sistem Tentang Kontrol Segi Hukum Terhadap Pemerintah Seri Ke-1: Perbandingan Hukum Administrasi dan Sistem Peradilan Administrasi (Edisi II dengan revisi), Citra Aditya Bakti, Bandung, 1993.

Peter Mahmud Marzuki, Penelitian Hukum, Kencana Prenada Media Group, Jakarta, 2005.

Philipus M. Hadjon, Perlindungan bagi Rakyat di Indonesia, Bina Ilmu, Surabaya, 1987.

Ridwan HR, Hukum Administrasi Negara, RajaGrafindo Persada, Jakarta, 2008.

Ronny Hanitijo Sumitro, Metodologi Penelitian Hukum, Ghlmia Indonesia, Jakarta, 1990.

Sahat HMT Sinaga, Notaris \& Badan Hukum Indonesia, Cetakan I, Jala Permata Aksara, Jakarta, 2019.

Salim HS, Hukum Kontrak-Teori dan Teknik Penyusunan Kontrak, Penerbit Sinar Grafika, Jakarta, 2006.

Satjipto Raharjo, Ilmu Hukum, Penerbit Alumni, Bandung, 1986.

Satjipto Raharjo, IImu Hukum, Cetakan ke-V, Citra Aditya Bakti, Bandung, 2000.

Setiono, Rule of Law (Supremasi Hukum), Penerbit Universitas Sebelas Maret, Surakarta, 2004.

Soerjono Soekanto dan Sri Mamudji, Penelitian Hukum Normatif, Rajawali Pers, Jakarta, 2011. 
Soerjono Soekanto, Tata Cara Penyusunan Karya Tulis IImiah Bidang Hukum, Ghalia Indonesia, 1983.

1986. ,Pengantar Penelitian Hukum, Penerbit Universitas Indonesia, Jakarta, , Sosiologi Suatu Pengantar, Raja Grafindo, Jakarta, 2002.

Soetardjo Soemoatmodjo, Apakah: Notaris, PPAT, Pejabat Lelang, Liberty, Yogyakarta, 1986.

Sudikno Mertokusumo, Bab-bab tentang Penemuan Hukum, cetakan ke I, Bandung, PT. Citra Aditya Bakti, 1993.

Tan Thong Kie, Studi Notariat Serba Serbi Notaris, Intermasa, Jakarta, 2007

Studi Notariat (Serba Serbi Praktik Notaris), Ichtiar Baru Van Hoeve, Jakarta, 2000.

Zainuddin Ali, Metode Penelitian Hukum, Sinar Grafika, Jakarta, 2018.

Philipus M. Hadjon, Tentang Wewenang Pemerintahan (Bestuurbevoegdheid), Pro Justitia Tahun XVI Nomor I Januari 1998, Jakarta.

Widyatmoko, Analisis Kritis Membedah Ketentuan Undang-Undang Republik Indonesia Nomor 2 Tahun 2014 tentang Perubahan Atas Undang-Undang Nomor 30 Tahun 2004 tentang Jabatan Notaris, Makalah Seminar Nasional Program Magister Kenotariatan Fakultas Hukum Serbelas Maret Surakarta, Surakarta, 2014.

Undang-Undang Dasar Negara Kesatuan Republik Indonesia Tahun 1945.

Kitab Undang-Undang Hukum Perdata (KUHPerdata).

Undang-Undang Nomor 30 Tahun 2004 tentang Jabatan Notaris.

Undang-Undang Republik Indonesia Nomor 2 Tahun 2014 tentang Perubahan Atas Undang-Undang Nomor 30 Tahun 2004 tentang Jabatan Notaris.

Majelis Permusyawaratan Rakyat Republik Indonesia, Panduan Pemasyarakatan UndangUndang Dasar Republik Indonesia Tahun 1945 (Sesuai dengan Urutan Bab, Pasal dan ayat), Sekertaris Jenderal MPR RI, 2010, Jakarta.

Lembaran Negara Republik Indonesia Tahun 2004 Nomor 117, Tambahan Lembaran Negara Republik Indonesia Nomor 4432.

Jimly Asshiddiqie, "Gagasan Negara Hukum". Melalui http://wsvw.Jimly.com/Makalah/ /Konsep, Selasa, 04 April 2021, pukul 16.00 WIB.

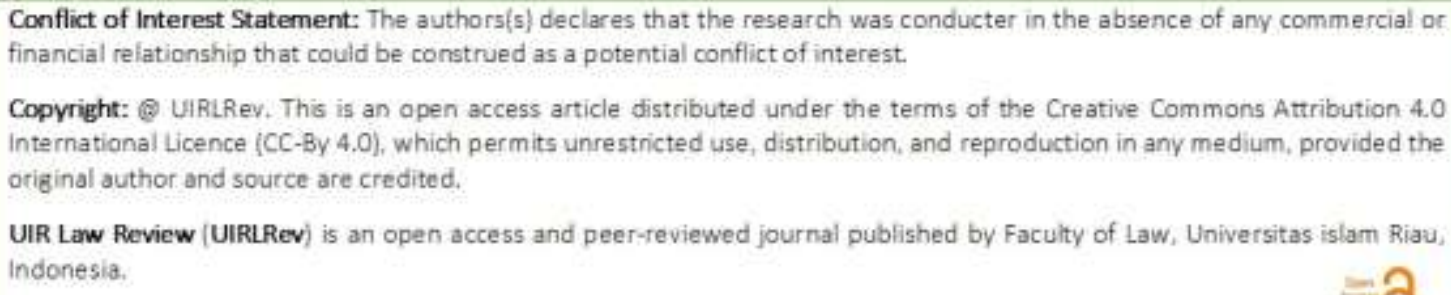

